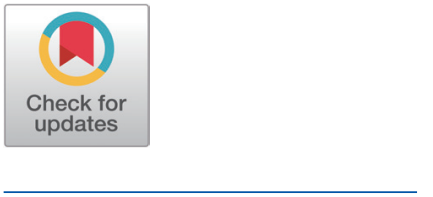

Received: Apr 21, 2021

Revised: Jul 6, 2021

Accepted: Sep 19, 2021

*Corresponding author

Xiangxue Xie

Ruminant Product Research and

Development Department, Guangdong

VTR Bio-Tech, Zhuhai 519060, China.

Tel: +86-756-8676888

E-mail: xxiangxue@163.com

Copyright $\odot 2021$ Korean Society of Animal Sciences and Technology.

This is an Open Access article distributed under the terms of the

Creative Commons Attribution

Non-Commercial License (http://

creativecommons.org/licenses/by-

$\mathrm{nc} / 4.0 /$ ) which permits unrestricted

non-commercial use, distribution, and

reproduction in any medium, provided

the original work is properly cited.

ORCID

Guoqiang Zhao

https://orcid.org/0000-0002-3684-9597

Hao Wu

https://orcid.org/0000-0003-1320-4603 Li Li

https://orcid.org/0000-0002-8976-6306 Jiajun $\mathrm{He}$

https://orcid.org/0000-0001-6999-6676

Zhichao Hu

https://orcid.org/0000-0003-0335-2311

Xinjian Yang

https://orcid.org/0000-0003-3812-3586

\title{
Effects of applying cellulase and starch on the fermentation characteristics and microbial communities of Napier grass (Pennisetum purpureum Schum.) silage
}

Guogiang Zhao ${ }^{1}$, Hao $\mathrm{Wu}^{2}$, Li Li ${ }^{1}$, Jiajun $\mathrm{He}^{1}$, Zhichao $\mathrm{Hu}^{1}$, Xinjian Yang ${ }^{1}$ and Xiangxue $\mathrm{Xie}^{1 *}$

${ }^{1}$ Ruminant Product Research and Development Department, Guangdong VTR Bio-Tech, Zhuhai 519060, China

${ }^{2}$ State Key Laboratory of Animal Nutrition, College of Animal Science and Technology, China Agricultural University, Beijing 100193, China

\section{Abstract}

This study investigated the effects of applying cellulase and starch on the fermentation characteristics and microbial communities of Napier grass silage after ensiling for $30 \mathrm{~d}$. Three groups were studied: No additives (control); added cellulase (Group 1); and added cellulase and starch (Group 2). The results showed that the addition of cellulase and starch decreased the crude protein (CP), neutral detergent fiber (NDF), acid detergent fiber (ADF) and $\mathrm{pH}$ significantly $(p<0.05)$ and increased water-soluble carbohydrate (WSC) content $(p<0.05)$. The addition of additives in two treated groups exerted a positive effect on the lactic acid (LA) content, lactic acid bacteria (LAB) population, and lactic acid / acetic acid (LA/AA) ratio, even the changes were not significant $(p>0.05)$. Calculation of Flieg's scores indicated that cellulase application increased silage quality to some extent, while the application of cellulase and starch together significantly improved fermentation $(p<0.05)$. Compared with the control, both additive groups showed increased microbial diversity after ensiling with an abundance of favorable bacteria including Firmicutes and Weissella, and the bacteria including Proteobacteria, Bacteroidetes, Acinetobacter increased as well. For alpha diversity analysis, the combined application of cellulase and starch in Group 2 gave significant increases in all indices ( $p$ $<0.05$ ). The study demonstrated that the application of cellulase and starch can increase the quality of Napier grass preserved as silage.

Keywords: Napier grass, Cellulase, Starch, Microbial community, Silage quality

\section{INTRODUCTION}

With the rapid development of the livestock industry, demand for feed resources is increasing annually. Good quality digestible forage has high nutritional value and is an essential part of the ruminant diet. It 
Xiangxue Xie

https://orcid.org/0000-0001-8216-1569

Competing interests

No potential conflict of interest relevant to

this article was reported.

Funding sources

This study was supported by a research project on the public welfare industry (Agriculture) from the Ministry of Agriculture of China (Grant number. 201503134).

Acknowledgements

Not applicable.

Availability of data and material Upon reasonable request, the datasets of this study can be available from the corresponding author.

\section{Authors' contributions}

Conceptualization: Zhao G, Wu H, Xie X.

Data curation: Zhao G, Li L, He J, Hu Z.

Formal analysis: Zhao G, Li L, He J, Hu Z.

Methodology: Zhao G, Li L.

Software: Zhao G, Li L.

Validation: Yang X, Xie X.

Investigation: He J, Yang X

Writing - original draft: Zhao G.

Writing - review \& editing: Wu H, Xie X.

Ethics approval and consent to participate This article does not require IRB/IACUC approval because there are no human and animal participants. can also be conserved to feed livestock during periods of shortage caused by limited pasture growth or inadequate conditions. However, efficient forage utilization can be compromised due to its high cellulose content, which is not easily degraded by rumen microbes. Thus, methods that improve forage utilization may help to alleviate feed resource shortages. Napier grass (Pennisetum purpureum Schum.) is a monocot grass that is widely cultivated and utilized in tropical and subtropical regions as a potential biofuel and forage crop. It is typically consumed as forage by ruminants as green chop, hay and silage; silage and hay are the two most common forms of forage preservation. In Southern China, especially Guangdong province, haymaking is restricted by unfavorable climatic conditions (high air moisture content, local precipitation, etc.). Consequently, ensiling has been widely proved to be an appropriate method for Napier grass preservation post-harvest [1,2]. Napier grass has a dry matter (DM) biomass productivity of $~ 40$ ton per hectare per year according to $\mathrm{Li}$ et al. [3]. However, the short-term consumption of Napier grass by livestock cannot be sustained due to its high growth rate and yield. Most tropical and subtropical grasses are difficult to ensile because of their low water-soluble carbohydrate (WSC) and high lignocellulosic contents [4]. Hence, supplementation with enzymes including cellulase which allows cell wall hydrolysis into fermentable substrates during ensiling was shown to be beneficial to lactic acid bacteria (LAB) growth by releasing glucose [5]. This enhanced fiber degradation and improved fermentation quality by reducing the $\mathrm{pH}$ [6]. Furthermore, supplementation with starch could provide an additional source of glucose to improve fermentation quality and accelerate the ensiling process.

Recent studies of Napier grass silage have mainly focused on fermentation characteristics arising from the use of various conventional additives such as LAB inoculants and cellulase $[7,8]$. Others have studied changes in the microbial communities of different forage species during ensiling $[9,10]$. However, there is little information available in southern China concerning the use of starch in silage and its effects on microbial communities, particularly during the ensiling of Napier grass. This study may provide a deeper insight into silage fermentation and provide a scientific basis for the development methods to regulate the production of high-quality silage from Napier grass. Hence the objective of this study was to investigate the effects of added cellulase and starch on the fermentation characteristics and microbial communities of Napier grass after ensiling for $30 \mathrm{~d}$.

\section{MATERIALS AND METHODS}

\section{Silage preparation}

Napier grass was cultivated in 2020 in an experimental trials field of VTR Bio-Tech (Doumen District, Zhuhai, Guangdong, China), located at $22^{\circ} 8^{\prime} 19^{\prime \prime} \mathrm{N}, 113^{\circ} 14^{\prime} 6^{\prime \prime} \mathrm{E}$, and an average sea level of $-7 \mathrm{~m}$. This experimental area was within the subtropical marine climate zone, and the soil type was Alfisols (as defined by the United States Department of Agriculture); annual mean temperature was $22.3^{\circ} \mathrm{C}$; average annual precipitation was $2,061.9 \mathrm{~mm}$; average annual wind speed was $3.0 \mathrm{~m} /$ s; and average annual humidity 78.7\%. The grass was harvested at the mature growth stage in April prior to chopping into lengths of $1-2 \mathrm{~cm}$. The chemical composition of the raw material before ensiling is shown in Table 1. The chopped Napier grass was divided into 3 groups: no additive (control); added cellulase (Group 1); and added cellulase and starch (Group 2). Cellulase was from Guangdong VTR Bio-Tech and soluble starch (food ingredient grade) was purchased from Guangzhou Chemical Reagent Factory (Guangzhou, China). Cellulase and starch were dissolved in distilled water as appropriate and applied evenly to the chopped Napier grass by spraying at levels of $120 \mathrm{U} / \mathrm{g}$ and $2 \%$ fresh matter respectively; an equivalent volume of distilled water was applied to the control group. After mixing thoroughly, three silos were prepared for each group and each group was ensiled in triplicate at room temperature using $0.5 \mathrm{~L}$ laboratory scale glass silos $(8 \mathrm{~cm}$ diameter 
Table 1. Chemical composition of Napier grass before and after ensiling

\begin{tabular}{|c|c|c|c|c|c|c|}
\hline \multirow{2}{*}{ Item } & DM & $\mathrm{CP}$ & ADF & NDF & WSC & Ash \\
\hline & $\mathrm{g} / \mathrm{kg}$ & \multicolumn{5}{|c|}{ g/ kg DM } \\
\hline \multicolumn{7}{|l|}{ Before ensiling } \\
\hline \multicolumn{7}{|l|}{ After ensiling } \\
\hline Control $^{1)}$ & 193.29 & $125.84^{\mathrm{a}}$ & $364.06^{a}$ & $625.46^{a}$ & $26.72^{b}$ & 124.85 \\
\hline SEM & 3.170 & 1.623 & 6.611 & 12.351 & 4.502 & 0.740 \\
\hline$p$-value & 0.395 & 0.030 & 0.018 & 0.015 & 0.003 & 0.602 \\
\hline
\end{tabular}

${ }^{1)}$ Control, no additives; Group 1, added cellulase; Group 2, added cellulase and starch.

${ }^{a, b}$ Means within a column with different superscripts differ $(p<0.05)$.

$\mathrm{DM}$, dry matter; CP, crude protein; ADF, acid detergent fiber; NDF, neutral detergent fiber; WSC, water-soluble carbohydrate.

$\times 16 \mathrm{~cm}$ height) sealed with lids. At day 30, the nine laboratory silos were opened, $300 \mathrm{~g}$ of silage was collected and sub-samples were treated as follows: samples for chemical composition analysis were oven-dried and ground subsequently prior to been tested, and the detail methods utilized were described as below; fresh samples for fermentation characteristics, microbial population and community analysis were collected and stored at $-80^{\circ} \mathrm{C}$ until required.

\section{Chemical composition analysis}

At day 30 , the sub-samples of silage were oven-dried at $65^{\circ} \mathrm{C}$ for $72 \mathrm{~h}$ and the DM contents calculated. Dried samples were ground and passed through a $1 \mathrm{~mm}$ mesh sieve and stored in sealed vinyl bags prior to chemical composition analysis. Crude protein $(\mathrm{CP})$ was determined by the Kjeldahl method according to the procedure of the Association of Official Analytical Chemists (AOAC, 1990) [11] using a K9860 Kjeldahl Analyzer (Hanon Advanced Technology Group, Jinan, China). Acid detergent fiber (ADF) and neutral detergent fiber (NDF) were measured by the method of Van Soest [12] using an ANKOM 2000 Automated Fiber Analyzer (Ankom Technologies, Fairport, NY, USA). WSC content was measured using a modified anthrone procedure [13]. Concentrations of ash before and after fermentation were measured using AOAC method [11].

\section{Fermentation characteristics}

Silage acidity was determined using an $\mathrm{AB} 150 \mathrm{pH}$ meter (Fisher Scientific International, Pittsburgh, PA, USA). Ammonia nitrogen $\left(\mathrm{NH}_{3}-\mathrm{N}\right)$ was analyzed by the phenol-hypochlorite reaction method [14]. Flieg's score was calculated from the formula given by Zhang et al. [15]. Lactic acid (LA) was determined by a high performance liquid chromatography (HPLC) system (Agilent HPLC 1260, Agilent Technologies, Santa Clara, CA, US) equipped with a UV detector (column: Agilent Hi-Plex $\mathrm{H}$; mobile phase: $5 \mathrm{mmol} / 1 \mathrm{H}_{2} \mathrm{SO}_{4}$; flow rate: $0.7 \mathrm{ml} / \mathrm{min}$; temperature: $\left.55^{\circ} \mathrm{C}\right)$; acetic acid $(\mathrm{AA})$, propionic acid $(\mathrm{PA})$ and butyric acid $(\mathrm{BA})$ were measured by gas chromatography (GC), the instrumental conditions were described according to Zhao et al. [16].

\section{Microbial population analysis}

Microbial populations were determined via the spread-plate method [17]. Samples (10 g) were homogenized in sterile conical flasks with sterile water $(90 \mathrm{~mL})$ and shaken for 30 minutes at room temperature. Serial dilutions ( $1 \mathrm{ml}$ of $10^{-4}$ to $10^{-7}$ ) were inoculated on the agar surface, spread evenly 
and counted after incubation. LAB were incubated on De Man, Rogosa and Sharpe agar at $37^{\circ} \mathrm{C}$ under anaerobic conditions and enumerated after $48 \mathrm{~h}$. Escherichia coli were incubated on violet red bile agar and enumerated after 18 to $24 \mathrm{~h}$ at $37^{\circ} \mathrm{C}$ under aerobic conditions. Viable mold and yeast were incubated on potato dextrose agar and enumerated after 48 to $72 \mathrm{~h}$ at $28^{\circ} \mathrm{C}$ under aerobic conditions. The microbial population data were collected as colony forming units (CFU) and transformed to a logarithmic scale on a fresh matter basis.

\section{Microbial community analysis}

Microbial community analysis was used to investigate changes in the diversity of bacteria during ensling. Briefly, total genome DNA was extracted from the silage samples using the cetyltrimethylammonium bromide method. DNA concentration and purity were monitored on $1 \%$ agarose gels, and based on this, the DNA was diluted to $1 \mathrm{ng} / \mu \mathrm{L}$ using sterile water. The distinct V3-V4 regions of $16 \mathrm{~S}$ rRNA were amplified and subsequently sequenced on NovaSeq 6000 platform (Novogene, Beijing, China). After sequencing, effective tags were produced by removing the barcodes and primers using "Fast Length Adjustment of Short" reads (FLASH; Version 1.2.7, available as open source code at http://ccb.jhu.edu/software/FLASH/) [18] according to the "Quantitative Insights Into Microbial Ecology" (QIIME; Version 1.9.1, available at http://qiime. org/scripts/split_libraries_fastq.html) [19] quality controlled process. The effective tags were then clustered into operational taxonomic units (OTUs) at a 97\% similarity level. According to the OTU results, alpha (Shannon, Simpson, Chao1 and coverage) and beta diversity (Principal component analysis [PCA]) were obtained using QIIME and R software (Version 2.15.3; R Foundation for Statistical Computing, Vienna, Austria), respectively.

\section{Statistical analysis}

The collected data were analyzed using the general linear model procedure in IBM SPSS Statistics for Windows, version 23.0 (IBM, Armonk, NY, USA). Duncan's test was utilized for multiple comparisons and significant differences were declared when $p<0.05$. Statistical analysis of microbial diversity including OTU analysis, alpha and beta diversity analysis were performed on the Novomagic platform (available at http://magic.novogene.com; Novogene, China).

\section{RESULTS AND DISCUSSION}

\section{Effects of additives on the chemical composition of Napier grass silage}

The highest DM content was found in Group 2 although this was not significantly different from the control $(p>0.05$; Table 1$)$. The $\mathrm{CP}$ content of Group 2 was significantly lower than the control and cellulase treated groups $(p=0.030)$ which could due to increased protein degradation during the ensiling process. Normally, two phases are formed during the protein degradation stage of silage fermentation. At the onset of fermentation, plant proteases hydrolyze proteins to peptides and amino acids, and these are subsequently degraded into various compounds which are metabolized by microbial protease rather than LAB [20,21]. Proteolysis during ensiling is affected by various of factors such as $\mathrm{pH}$ [22], and the initial DM [23] and WSC contents of the forage species [24]. The lower CP content in Group 2 might due to the increased proteolysis activities after adding cellulase and starch during fermentation, but the specific synergy mechanism among them remained unknown till now. Tao et al. [25] also observed similar results in alfalfa when ensiled with sweet sorghum. Previous studies have demonstrated that cellulase application to silage materials can improve fermentation quality by decreasing the NDF and ADF contents during ensiling [26-28]. A similar trend was observed here with decreased amounts of NDF and 
ADF, possibly due to the enzymolysis and acid solubilization of cellulose, hemicellulose and lignin during fermentation [29]. Compared with the control and Group 1, this decrease was significantly greater in Group 2 following the combined addition of cellulase and starch $(p<0.05)$. Jones et al. [30] demonstrated that adding starch to rye silage increased the WSC content by $3 \%-4 \%$ after ensiling, thus improving the silage quality. Here, the residual WSC content of Group 2 was higher than Group 1 and the control $(p<0.05)$; an increase was also detected in Group 1, possibly due to the hydrolysis of starch during ensiling, although the effect was not significant $(p>0.05)$. No significant differences were found in ash contents of the three groups, however, when compared to raw materials prior to ensiling, the three groups showed numerically increases. It was in line with the results of Rahjerdi et al. [31] on amaranth-corn combination silage.

\section{Effect of additives on the fermentation characteristics of Napier grass silage}

Fermented silage usually shows a decrease in $\mathrm{pH}$ (Table 2). Compared with the control, both additive groups showed a reduction in $\mathrm{pH}(p<0.05)$. The ratio of $\mathrm{NH}_{3}-\mathrm{N}$ to total nitrogen is a critical index that can indicate the extent of proteolysis during ensiling; $\mathrm{NH}_{3}-\mathrm{N}$ is produced from protein decomposition in fresh ensiling materials by the activity of Clostridium spp. [32]. The $\mathrm{NH}_{3}-\mathrm{N}$ content in silage is an indicator of silage fermentation quality; a high $\mathrm{NH}_{3}-\mathrm{N}$ content indicates a lower fermentation quality. In this study, no significant difference was found between all the groups $(p=0.826)$. LA is the main acid product produced by LAB from sugar substrates during ensiling; a higher LA concentration reflects increased conversion efficiency from WSC. Compared with the control, the applications of cellulase or cellulase / starch both increased the LA concentration of the silage $(p<0.05)$; the highest value was found in Group 2. Hence, the application of cellulase alone, or combined with starch, could facilitate the availability of enough substrate for increased LA production by LAB. In addition, added starch, in combination with cellulase, improved the quality of the silage. Numerical, but not significant, increases $(p>0.05)$ in AA were also detected in control, Group 1 and Group 2. AA is produced by Enterobacteria and heterofermentative LAB and, to some extent, a higher content might relate to increased DM loss [33]. PA was only detected in the control group. BA is also an indicator of poor fermentation quality, and it can reflect the activity of unfavorable Clostridium spp. during silage fermentation. Silage with relatively high BA levels might also be less palatable to livestock [34]. A good-medium grade silage might contain 5-10 g/ $/ \mathrm{kg}$ DM BA [4,35]. No BA was detected in all the groups of this study, indicating that the activity of Clostridium spp. was inhibited during fermentation, rendering the silage preserved. According to Jones et al. [36], the ratio of LA to AA can reflect the extent of homolactic and heterolactic fermentation during ensiling. The silage treated with additives was

Table 2. Effects of applying additives on fermentation characteristics of Napier grass silage

\begin{tabular}{|c|c|c|c|c|c|c|c|c|c|}
\hline \multirow{2}{*}{ Group } & \multirow{2}{*}{$\mathrm{pH}$} & $\mathrm{NH}_{3}-\mathrm{N} / \mathrm{TN}$ & LA & AA & PA & BA & LA/AA & \multirow{2}{*}{$\begin{array}{l}\text { Flieg's } \\
\text { score }^{1 /}\end{array}$} & \multirow{2}{*}{ Grade } \\
\hline & & & & $\mathrm{g} / \mathrm{kg} \mathrm{DM}$ & & & $\%$ & & \\
\hline Control $^{2)}$ & $4.72^{a}$ & 258.47 & 15.19 & 0.76 & 0.28 & ND & 20.11 & $57.01^{b}$ & Average \\
\hline Group 1 & $4.49^{b}$ & 272.55 & 19.49 & 0.84 & ND & ND & 23.22 & $64.19^{b}$ & Good \\
\hline Group 2 & $4.32^{c}$ & 271.26 & 23.34 & 1.01 & ND & ND & 27.67 & $73.02^{\mathrm{a}}$ & Good \\
\hline SEM & 0.062 & 8.133 & 1.610 & 0.063 & - & - & 1.959 & 2.580 & - \\
\hline$p$-value & 0.002 & 0.826 & 0.126 & 0.287 & - & - & 0.383 & 0.012 & - \\
\hline
\end{tabular}

${ }^{1)}$ Flieg's scores (0-100) were ranked into five grades: Poor (0-20), Fair (21-40), Average (41-60), Good (61-80), and Excellent (81-100).

${ }^{2)}$ Control, no additives; Group 1, added cellulase; Group 2, added cellulase and starch.

a-c Means within a column with different superscripts differ $(p<0.05)$.

$\mathrm{NH}_{3}-\mathrm{N}$, ammonium nitrogen; TN, total nitrogen; LA, lactic acid; AA, acetic acid; PA, propionic acid; BA, butyric acid; DM, dry matter; ND, not detected; -, default. 
dominated by LA rather than AA, indicating that homolactic fermentation was the major pathway. In addition, Bolsen [34] showed that silage produced without additives, such as the control in this study, may be less palatable to cattle. The silage was be ranked into five grades based on Flieg's score; the cellulase and starch group were ranked as 'Good' and the control group was ranked 'Average'(Table 2).

Overall, cellulase application improved silage quality while the combination of starch and cellulase improved the fermentation characteristics of the Napier grass silage.

\section{Effects of additives on the microbial population of Napier grass silage}

It is known that $\mathrm{LAB}$ are the dominant microbes during silage fermentation once anaerobic conditions are established and under these conditions, the growth of some undesirable microorganisms can be inhibited by bacteriocins produced by certain strains of LAB [37]. So, to some extent, higher populations of LAB may lead to improved fermentation quality. The LAB populations were elevated in the silage from Group 1 and Group 2 although the differences were not significant $(p=0.573)$. The results suggested that the additions of cellulase and starch may promote the growth of LAB during ensiling, but further studies may be required to understand the optimum dosage. Spoilage organisms such as Escherichia coli, mold and yeast are additional indicators of poor fermentation. Yeast is one of the detrimental microorganisms in silage fermentation which can cause secondary fermentation. Mold growth is promoted by aerobic exposure, e.g., when silos are not sufficiently sealed, resulting in decreased fermentation quality. Table 3 shows that $E$. coli, mold and yeast were not detected in any group. This could be attributed to inhibition of adventitious microbes by the low $\mathrm{pH}$ under fermentation conditions.

\section{Microbial community of Napier grass silage treated by different additives}

\section{Shared operational taxonomic unit analysis}

The Venn diagram given in Fig. 1 shows the shared and unique OTUs among the three groups in this study. Table 4 shows the respective number of OTUs in each group. A total of 166 OTUs were clustered at the $97 \%$ similarity level. From the 58 common OTUs, 29, 27 and 52 were unique to the control, Group 1 and Group 2 respectively. Compared with the other groups, Group 2 showed a numerical increase indicating a higher diversity to some extent after fermentation, although this was not statistically significant $(p=0.602)$. The higher diversity shown by Group 2 might be attributed to the addition of cellulase and starch which provided sufficient fermentation substrate to promote microbial growth and diversity [38].

\section{Bacterial community analysis}

The relative abundance of bacterial communities in each group at the phylum (a) and genus (b) levels are shown in Fig. 2.

Table 3. Effects of applying additives on microbial population of Napier grass silage

\begin{tabular}{lcccc}
\hline \multirow{2}{*}{ Group } & LAB & E. coli & Mold & Yeast \\
\cline { 2 - 5 } & \multicolumn{5}{c}{ Log CFU/g of FM } \\
\hline Control $^{1)}$ & 7.96 & ND & ND & ND \\
Group 1 & 8.15 & ND & ND & ND \\
Group 2 & 8.22 & ND & ND & ND \\
SEM & 0.087 & - & - & - \\
$p$-value & 0.573 & - & - & - \\
\hline
\end{tabular}

${ }^{11}$ Control, no additives; Group 1, added cellulase; Group 2, added cellulase and starch.

LAB, lactic acid bacteria; E.coli, Escherichia coli;; CFU, colony forming units; FM, fresh matte; ND, not detected. 


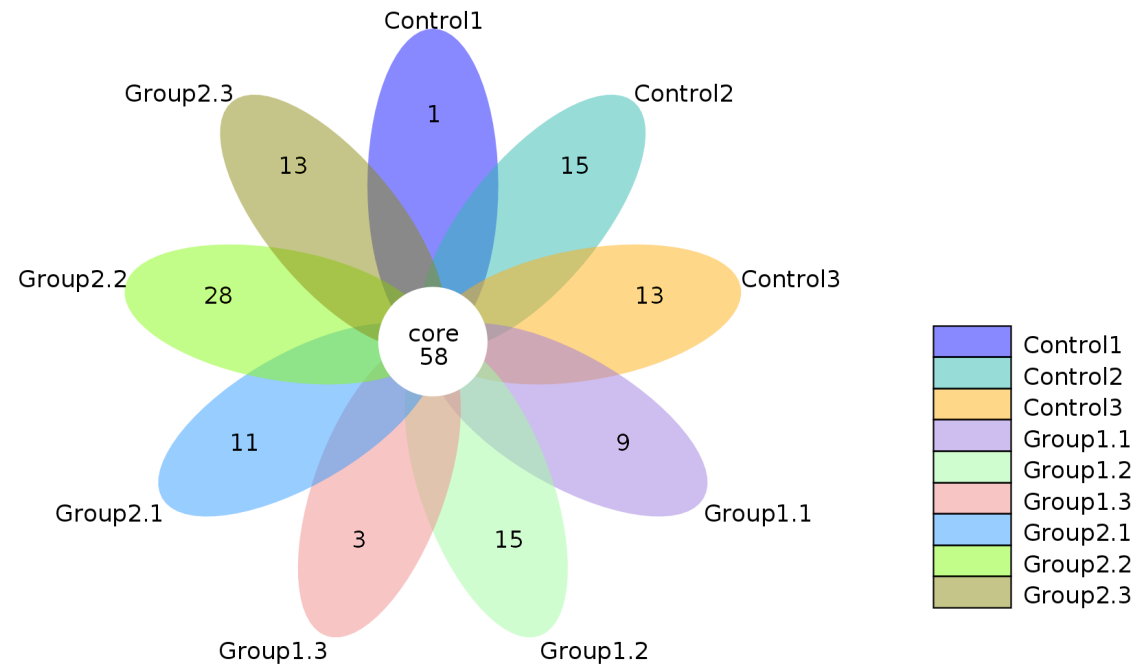

Fig. 1. Venn analysis of operational taxonomic units (OTUs) for Napier grass silage. Control, no additives; Group 1, added cellulase; Group 2, added cellulase and starch.

Table 4. OTUs number and Alpha diversity indices of microbial community for Napier grass silage

\begin{tabular}{lccccccc}
\hline \multicolumn{1}{c}{ Group } & $\begin{array}{c}\text { OTUs } \\
\text { number }\end{array}$ & $\begin{array}{c}\text { Observed } \\
\text { species }\end{array}$ & Shannon & Simpson & Chao1 & $\begin{array}{c}\text { Goods- } \\
\text { coverage }\end{array}$ \\
\hline Control $^{1)}$ & 68 & $195^{\mathrm{b}}$ & $3.074^{\mathrm{b}}$ & $0.755^{\mathrm{b}}$ & $212^{\mathrm{b}}$ & $213^{\mathrm{b}}$ & 0.999 \\
Group1 & 67 & $173^{\mathrm{b}}$ & $3.627^{\mathrm{a}}$ & $0.868^{\mathrm{a}}$ & $199^{\mathrm{b}}$ & $202^{\mathrm{b}}$ & 0.999 \\
Group2 & 75 & $243^{\mathrm{a}}$ & $3.585^{\mathrm{a}}$ & $0.843^{\mathrm{a}}$ & $269^{\mathrm{a}}$ & $268^{\mathrm{a}}$ & 0.999 \\
SEM & 2.603 & 11.425 & 0.102 & 0.020 & 11.284 & 10.971 & - \\
p-value & 0.399 & 0.004 & 0.014 & 0.017 & 0.001 & 0.002 & - \\
\hline
\end{tabular}

${ }^{1)}$ Control, no additives; Group 1, added cellulase; Group 2, added cellulase and starch.

${ }^{a, b}$ Means within a column with different superscripts differ $(p<0.05)$.

OTUs, operational taxonomic units.

At the phylum level (Fig. 2A), Firmicutes, Cyanobacteria and Proteobacteria were the dominant microbes in three groups, which was consistent with previous studies [39, 40]. Among these, Firmicutes were the most abundant bacteria and their population increased numerically $(p>0.05)$ in both additive groups (control, 59.39\%; Group 1, 62.34\%; Group 2, 64.67\%). Firmicutes are important acid-producing hydrolytic bacteria that can proliferate under the low $\mathrm{pH}$ conditions of silage fermentation [41]. The increased abundance of Proteobacteria in both additive groups (23.37\% and $11.71 \%$, respectively; $p<0.05)$, compared with the control group (6.13\%) indicated a favorable shift in the microbial community following the additive applications.

At the genus level, Lactobacillus, unidentified Cyanobacteria, Lactococcus, Weissella and Pantoea were identified (Fig. 2B). It is commonly known that Lactobacillus, Lactococcus and Weissella are the LAB present during the ensiling of high-quality silage $[42,43]$. To date, several studies have shown that Lactobacillus comprises the main microbial community during ensiling and their abundance is closely associated with silage quality [44,45]. Here, Lactobacillus was also the predominant community during ensiling, which was in consistent with the results from previous studies [41,46,47]. Interestingly, Wang et al. [48] reported that Exiguobacterium was the dominant bacteria in silage prepared from Moringa oleifera leaves. However, this result could be due to the different silage materials used. Although the abundance of unidentified Cyanobacteria decreased $(p$ 
A

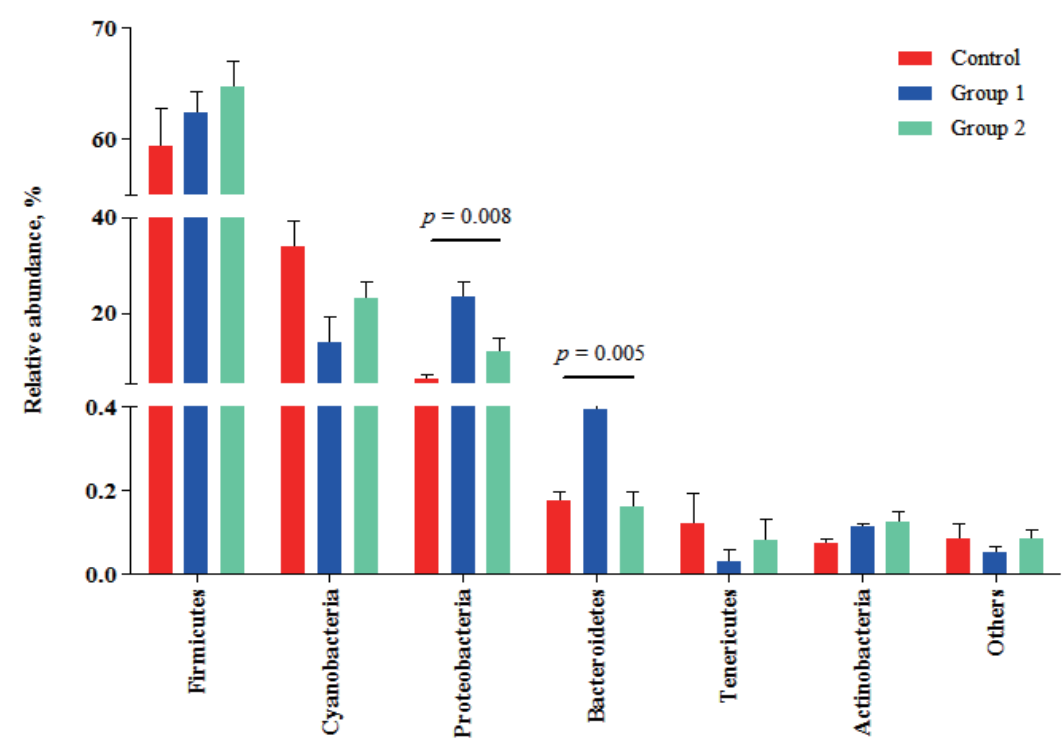

B

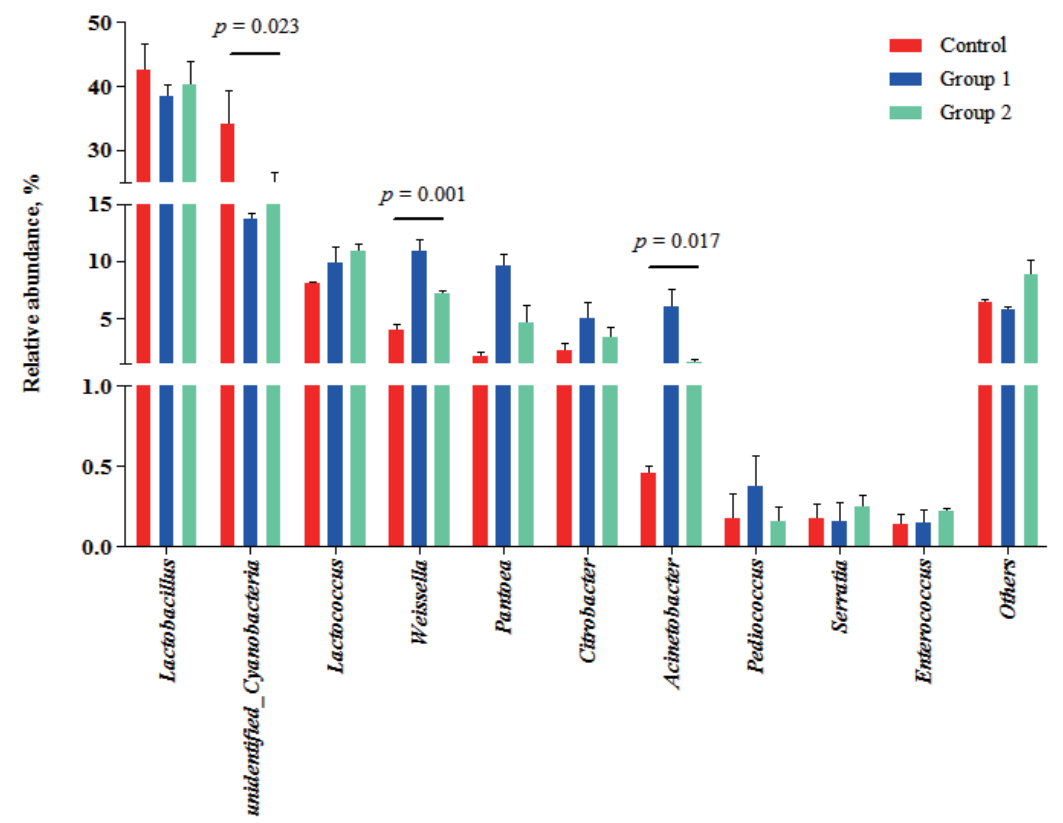

Fig. 2. Relative abundance of microbial community on phylum (a) and genus (b) level for Napier grass silage. Control, no additives; Group 1, added cellulase; Group 2, added cellulase and starch.

$<0.05)$ in the Group $1(13.70 \%)$ and Group 2 (23.17\%), compared with the control (34.03\%), the dynamics and mechanisms of these bacteria in silage fermentation are unclear as they have not been studied in detail. Group 1 and Group 2 showed small changes in the abundance of Lactobacillus and Lactococcus communities. However, for Weissella bacteria, which are obligated heterofermentative bacteria that can outcompete Lactobacillus in the latter stage of fermentation [49], both Group $1(10.89 \%)$ and Group $2(7.14 \%)$ showed increased abundances $(p<0.05)$ relative to the Control (4.05\%). These observations were also consistent with the increased LA production and reduced $\mathrm{pH}$ in Group 1 and Group 2 silage and reflect the positive role of the cellulase and starch during the fermentation of Napier grass silage. 


\section{Alpha diversity}

The Shannon and Simpson indices reflect microbial community richness while chao 1 and ACE indicate microbial diversity; microbial community richness is inversely associated with diversity, e.g., as richness increases, the diversity decreases and vice versa [50]. The alpha diversity indices for each group are given in Table 4.

The coverage values for the silage samples were all $>0.999$, indicating that the sequencing data were sufficiently large to cover the entire profile of the microbial community. The highest observed species ranged from 173 to 243, which was greater than values reported elsewhere [49]. However, the latter was obtained from the analysis of silage produced from different ensiling materials (Neolamarckia cadamba leaves) and fermentation duration. The cellulase treated group (Group 1) showed significant increases in the Shannon and Simpson indices $(p<0.05)$ and numerical decreases in Chao 1 and $\mathrm{ACE}(p>0.05)$, indicating that added cellulase decreased microbial community richness but increased diversity to some extent in the Napier grass silage. The low $\mathrm{pH}$ value in cellulase treated group caused by higher LA production might be the main factor underlying affected microbial diversity [51]. And Zheng et al. [52] also stated that lower microbial community richness were related to the disappearance of some epiphytic bacteria due to their lower adaptability to the anaerobic condition and acidic environment during ensiling. Interestingly, the combined application of cellulase and starch (Group 2) gave significant increases in all indices $(p<$ 0.05). This could be due to some unknown synergistic effect of cellulase and starch during ensiling which altered the diversity of the microbial community. A similar phenomenon was also obtained for silage produced from Neolamarckia cadamba leaves [49].

\section{Beta diversity}

To further evaluate the differences in microbial communities between the samples from different groups, beta diversity analysis was performed using PCA (Fig. 3). The contribution of the two

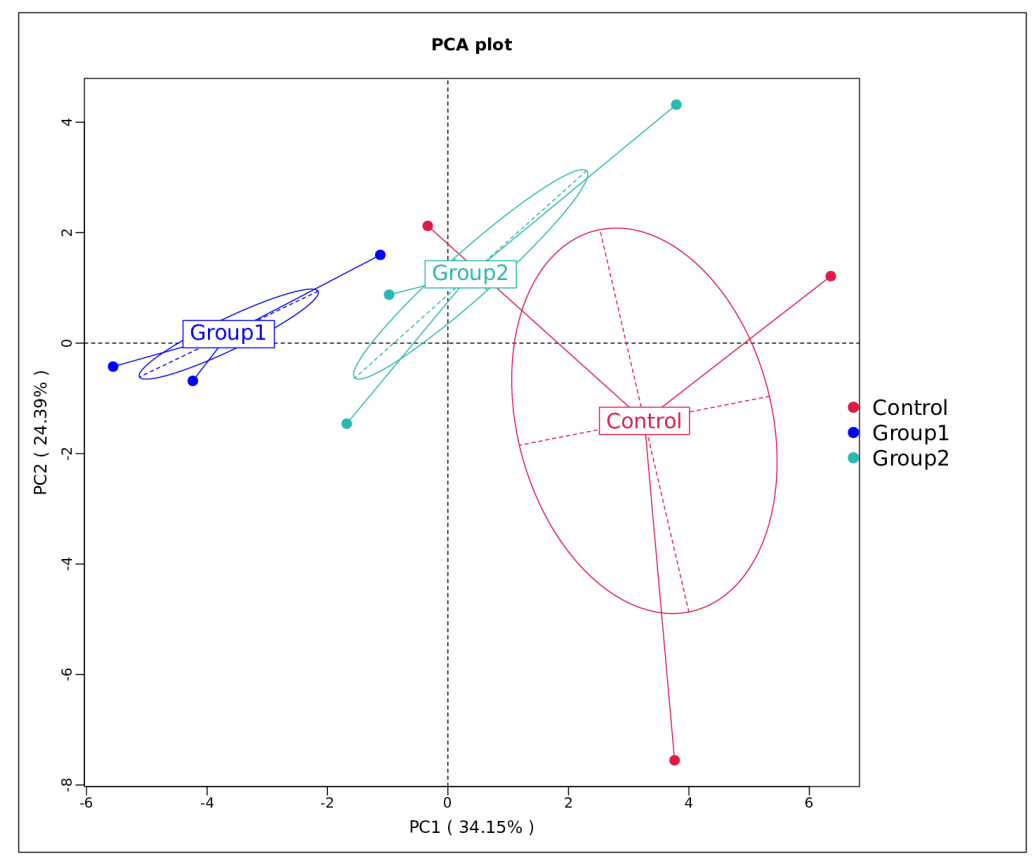

Fig. 3. Principal component analysis (PCA) of microbial community for Napier grass silage. Control, no additives; Group 1, added cellulase; Group 2, added cellulase and starch. 
principal components to the total variance were $34.15 \%$ and $24.39 \%$, respectively. Parvin et al. [53] showed that silage samples with different microbial communities tended to separate, while similar communities gathered together. Fig. 3 shows that the control, Group 1 and Group 2 formed three separate distributions, suggesting that the application of additives exerted an effect on the microbial community during ensiling. The three replicate results of the control group distributed more widely than the replicates from the additive groups suggesting that the microbial communities in Group 1 and Group 2 were more stable.

These results demonstrated that both additives exerted a positive effect on the microbial communities of Napier grass silage, while the variances may help to explain the differences in silage fermentation quality resulting from different treatments.

\section{CONCLUSIONS}

This study showed that the combined application of cellulase and starch to Napier grass decreased $\mathrm{CP}, \mathrm{ADF}, \mathrm{NDF}$ and $\mathrm{pH}$, while, WSC, LA, Flieg's score and the LAB population increased postensiling. Microbial community analysis showed that both additives improved the abundance of favorable microbes such as Firmicutes and Weissella, and the bacteria including Proteobacteria, Bacteroidetes, Acinetobacter increased as well. Taking all results above into consideration, added cellulase exerted a small positive effect on Napier grass silage quality; while the combined application of cellulase and starch increased fermentation quality and the abundance of favorable microbial communities. Consequently, these results have demonstrated that the combined application of cellulase and starch additives is recommended for high-quality Napier grass silage preservation.

\section{REFERENCES}

1. Ali N, Wang S, Zhao J, Dong Z, Li J, Nazar M, et al. Using a high-throughput sequencing technology to evaluate the various forage source epiphytic microbiota and their effect on fermentation quality and microbial diversity of Napier grass. Arch Microbiol. 2021;203:4879-90. https://doi.org/10.1007/s00203-021-02296-5

2. Cai Y, Du Z, Yamasaki S, Nguluve D, Tinga B, Macome F, et al. Influence of microbial additive on microbial populations, ensiling characteristics, and spoilage loss of delayed sealing silage of Napier grass. Asian-Australas J Anim Sci. 2020;33:1103-12. https://doi.org/10.5713/ ajas.19.0471

3. Li J, Yuan X, Desta ST, Dong Z, Mugabe W, Shao T. Characterization of Enterococcus faecalis JF85 and Enterococcus faecium Y83 isolated from Tibetan yak (Bos grunniens) for ensiling Pennisetum sinese. Bioresour Technol. 2018;257:76-83. https://doi.org/10.1016/ j.biortech.2018.02.070

4. Mcdonald P, Henderson N, Heron S. The biochemistry of silage. 2nd ed. Marlow: Chalcombe; 1991.

5. Dehghani MR, Weisbjerg MR, Hvelplund T, Kristensen NB. Effect of enzyme addition to forage at ensiling on silage chemical composition and NDF degradation characteristics. Livest Sci. 2012;150:51-8. https://doi.org/10.1016/j.livsci.2012.07.031

6. Desta ST, Yuan X, Li J, Shao T. Ensiling characteristics, structural and nonstructural carbohydrate composition and enzymatic digestibility of Napier grass ensiled with additives. Bioresour Technol. 2016;221:447-54. https://doi.org/10.1016/j.biortech.2016.09.068

7. Gulfam A, Guo G, Tajebe S, Chen L, Liu Q, Yuan X, et al. Characteristics of lactic acid bac- 
teria isolates and their effect on the fermentation quality of Napier grass silage at three high temperatures.J Sci Food Agric. 2017;97:1931-8. https://doi.org/10.1002/jsfa.7998

8. Khota W, Pholsen S, Higgs D, Cai Y. Comparative analysis of silage fermentation and in vitro digestibility of tropical grass prepared with Acremonium and Tricoderma species producing cellulases. Asian-Australas J Anim Sci. 2018;31:1913-22. https://doi.org/10.5713/ajas.18.0083

9. Ali N, Wang S, Zhao J, Dong Z, Li J, Nazar M, Shao T. Microbial diversity and fermentation profile of red clover silage inoculated with reconstituted indigenous and exogenous epiphytic microbiota. Bioresour Technol. 2020;314:123606. https://doi.org/10.1016/j.biortech. 2020.123606

10. Dong M, Li Q, Xu F, Wang S, Chen J, Li W. Effects of microbial inoculants on the fermentation characteristics and microbial communities of sweet sorghum bagasse silage. Sci Rep. 2020;10:837.https://doi.org/10.1038/s41598-020-57628-0

11. AOAC [Association of Official Analytical Chemists]. Official methods of analysis. 15th ed. Arlington, VA: AOAC; 1990.

12. Van Soest PJ, Robertson JB, Lewis BA. Methods for dietary fiber, neutral detergent fiber, and nonstarch polysaccharides in relation to animal nutrition.J Dairy Sci. 1991;74:3583-97. https:// doi.org/10.3168/jds.S0022-0302(91)78551-2

13. Yemm EW,Willis AJ. The estimation of carbohydrates in plant extracts by anthrone. Biochem J. 1954;57:508-14. https://doi.org/10.1042/bj0570508

14. Broderick GA, Kang JH. Automated simultaneous determination of ammonia and total amino acids in ruminal fluid and in vitro media.J Dairy Sci. 1980;63:64-75. https://doi.org/10.3168/ jds.S0022-0302(80)82888-8

15. Zhang XQ, Jin YM, Zhang YJ, Yu Z, Yan WH. Silage quality and preservation of Urtica cannabina ensiled alone and with additive treatment. Grass Forage Sci. 2014;69:405-14. https:// doi.org/10.1111/gfs.12036

16. Zhao GQ, Wei SN, Liu C, Kim HJ, Kim JG. Effect of harvest dates on $\beta$-carotene content and forage quality of rye (Secale cereale L.) silage and hay. J Anim Sci Technol. 2021;63:35466. https://doi.org/10.5187/jast.2021.e28

17. Madigan MT, Martinko JM, Stahl DA, Clark DP. Brock biology of microorganisms. 13th ed. Boston, MA: Pearson; 2012.

18. Magoč T, Salzberg SL. FLASH: fast length adjustment of short reads to improve genome assemblies. Bioinformatics. 2011;27:2957-63. https://doi.org/10.1093/bioinformatics/btr507

19. Caporaso JG, Kuczynski J, Stombaugh J, Bittinger K, Bushman FD, Costello EK, et al. QIIME allows analysis of high-throughput community sequencing data. Nat Methods. 2010;7:335-6. https://doi.org/10.1038/nmeth.f.303

20. Kemble AR. Studies on the nitrogen metabolism of the ensilage process. J Sci Food Agric. 1956;7:125-30. https://doi.org/10.1002/jsfa.2740070206

21. Ohshima M, Mcdonald P. A review of the changes in nitrogenous compounds of herbage during ensilage.J Sci Food Agric. 1978;29:497-505. https://doi.org/10.1002/jsfa.2740290602

22. Jones BA, Hatfield RD, Muck RE. Characterization of proteolysis in alfalfa and red clover. Crop Sci. 1995;35:537-41. https://doi.org/10.2135/cropsci1995.0011183X003500020043x

23. Pitt RE, Muck RE, Leibensperger RY. A quantitative model of the ensilage process in lactate silages. Grass Forage Sci. 1985;40:279-303. https://doi.org/10.1111/j.1365-2494.1985. tb01755.x

24. Fijałkowska M, Pysera B, Lipiński K, Strusińska D. Changes of nitrogen compounds during ensiling of high protein herbages - a review. Ann Anim Sci. 2015;15:289-305. https:/doi. org/10.1515/aoas-2015-0008 
25. Tao Y, Sun Q, Li F, Xu C, Cai Y. Comparative analysis of ensiling characteristics and protein degradation of alfalfa silage prepared with corn or sweet sorghum in semiarid region of Inner Mongolia. Anim Sci J. 2019;91:e13321. https://doi.org/10.1111/asj.13321

26. He L, Zhou W, Wang Y, Wang C, Chen X, Zhang Q. Effect of applying lactic acid bacteria and cellulase on the fermentation quality, nutritive value, tannins profile and in vitro digestibility of Neolamarckia cadamba leaves silage. J Anim Physiol Anim Nutr. 2018;102:1429-36. https://doi.org/10.1111/jpn.12965

27. Su R, Ni K, Wang T, Yang X, Zhang J, Liu Y, et al. Effects of ferulic acid esterase-producing Lactobacillus fermentum and cellulase additives on the fermentation quality and microbial community of alfalfa silage. PeerJ. 2019;7:e7712. https://doi.org/10.7717/peerj.7712

28. Wang S, Guo G, Li J, Chen L, Dong Z, Shao T. Improvement of fermentation profile and structural carbohydrate compositions in mixed silages ensiled with fibrolytic enzymes, molasses and Lactobacillus plantarum MTD-1. Ital J Anim Sci. 2019;18:328-35. https://doi.org/10.108 0/1828051X.2018.1528899

29. Li M, Zhou H, Zi X, Cai Y. Silage fermentation and ruminal degradation of stylo prepared with lactic acid bacteria and cellulase. Anim Sci J. 2017;88:1531-7. https://doi.org/10.1111/ asj.12795

30. Jones DIH. The effect of cereal incorporation on the fermentation of spring- and autumn-cut silages in laboratory silos. Grass Forage Sci. 1988;43:167-72. https://doi.org/10.1111/j.13652494.1988.tb01884.x

31. Rahjerdi NK, Rouzbehan Y, Fazaeli H, Rezaei J. Chemical composition, fermentation characteristics, digestibility, and degradability of silages from two amaranth varieties (Kharkovskiy and Sem), corn, and an amaranth-corn combination.J Anim Sci. 2015;93:5781-90. https://doi. org/10.2527/jas.2015-9494

32. Tian J, Yu Y, Yu Z, Shao T, Na R, Zhao M. Effects of lactic acid bacteria inoculants and cellulase on fermentation quality and in vitro digestibility of Leymus chinensis silage. Grassl Sci. 2014;60:199-205. https://doi.org/10.1111/grs.12059

33. Kim JG, Chung ES, Seo S, Ham JS, Kang WS, Kim DA. Effects of maturity at harvest and wilting days on quality of round baled rye silage. Asian-Australas J Anim Sci. 2001;14:1233-7. https://doi.org/10.5713/ajas.2001.1233

34. Bolsen KK. Silage: basic principles. In: Barnes RF, Miller DA, Nelson CJ, editors. Forages, volume II: the science of grassland agriculture. 5th ed. Ames, IA: Iowa State University Press; 1995.p. 163-76.

35. Wieringa GW. The influence of nitrate on silage fermentation. In: Proceedings of the 4th International Grassland Congress;1966; Helsinki. pp. 537-40.

36. Jones BA, Satter LD, Muck RE. Influence of bacterial inoculant and substrate addition to lucerne ensiled at different dry matter contents. Grass Forage Sci. 1992;47:19-27. https://doi. org/10.1111/j.1365-2494.1992.tb02243.x

37. Gollop N, Zakin V, Weinberg ZG. Antibacterial activity of lactic acid bacteria included in inoculants for silage and in silages treated with these inoculants. J Appl Microbiol. 2005;98:6626. https://doi.org/10.1111/j.1365-2672.2004.02504.x

38. Wang Y, He L, Xing Y, Zhou W, Pian R, Yang F, et al. Bacterial diversity and fermentation quality of Moringa oleifera leaves silage prepared with lactic acid bacteria inoculants and stored at different temperatures. Bioresour Technol. 2019;284:349-58. https://doi.org/10.1016/ j.biortech.2019.03.139

39. Chen LY, Bai S, You M, Xiao B, Li P, Cai Y. Effect of a low temperature tolerant lactic acid bacteria inoculant on the fermentation quality and bacterial community of oat round bale silage. 
Anim Feed Sci Technol. 2020;269:114669. https://doi.org/10.1016/j.anifeedsci.2020.114669

40. Wang S, Zhao J, Dong Z, Li J, Kaka NA, Shao T. Sequencing and microbiota transplantation to determine the role of microbiota on the fermentation type of oat silage. Bioresour Technol. 2020;309:123371. https://doi.org/10.1016/j.biortech.2020.123371

41. Romero JJ, Zhao Y, Balseca-Paredes MA, Tiezzi F, Gutierrez-Rodriguez E, Castillo MS. Laboratory silo type and inoculation effects on nutritional composition, fermentation, and bacterial and fungal communities of oat silage. J Dairy Sci. 2017;100:1812-28. https://doi.org/10.3168/ jds.2016-11642

42. Ni K, Zhao J, Zhu B, Su R, Pan Y, Ma J, et al. Assessing the fermentation quality and microbial community of the mixed silage of forage soybean with crop corn or sorghum. Bioresour Technol. 2018;265:563-7. https://doi.org/10.1016/j.biortech.2018.05.097

43. Yang J, Tan H, Cai Y. Characteristics of lactic acid bacteria isolates and their effect on silage fermentation of fruit residues. J Dairy Sci. 2016;99:5325-34. https://doi.org/10.3168/jds.201610952

44. Ni K, Wang Y, Cai Y, Pang H. Natural lactic acid bacteria population and silage fermentation of whole-crop wheat. Asian-Australas J Anim Sci. 2015;28:1123-32. https://doi.org/10.5713/ ajas.14.0955

45. Xu S, Yang J, Qi M, Smiley B, Rutherford W, Wang Y, et al. Impact of Saccharomyces cerevisiae and Lactobacillus buchneri on microbial communities during ensiling and aerobic spoilage of corn silage1.J Anim Sci. 2019;97:1273-85. https://doi.org/10.1093/jas/skz021

46. Yan Y, Li X, Guan H, Huang L, Ma X, Peng Y, et al. Microbial community and fermentation characteristic of Italian ryegrass silage prepared with corn stover and lactic acid bacteria. Bioresour Technol. 2019;279:166-73. https://doi.org/10.1016/j.biortech.2019.01.107

47. Yang L, Yuan X, Li J, Dong Z, Shao T. Dynamics of microbial community and fermentation quality during ensiling of sterile and nonsterile alfalfa with or without Lactobacillus plantarum inoculant. Bioresour Technol. 2019;275:280-7. https://doi.org/10.1016/j.biortech.2018.12.067

48. Wang Y, Wang C, Zhou W, Yang F, Chen X, Zhang Q. Effects of wilting and Lactobacillus plantarum addition on the fermentation quality and microbial community of Moringa oleifera leaf silage. Front Microbiol. 2018;9:1817. https://doi.org/10.3389/fmicb.2018.01817

49. He L, Wang C, Xing Y, Zhou W, Pian R, Yang F, et al. Dynamics of proteolysis, protease activity and bacterial community of Neolamarckia cadamba leaves silage and the effects of formic acid and Lactobacillus farciminis. Bioresour Technol. 2019;294:122127. https://doi. org/10.1016/j.biortech.2019.122127

50. Ogunade IM, Jiang Y, Pech Cervantes AA, Kim DH, Oliveira AS, Vyas D, et al. Bacterial diversity and composition of alfalfa silage as analyzed by Illumina MiSeq sequencing: effects of Escherichia coli O157:H7 and silage additives. J Dairy Sci. 2018;101:2048-59. https://doi. org/10.3168/jds.2017-12876

51. Méndez-García C, Peláez AI, Mesa V, Sánchez J, Golyshina OV, Ferrer M. Microbial diversity and metabolic networks in acid mine drainage habitats. Front Microbiol. 2015;6:475. https:// doi.org/10.3389/fmicb.2015.00475

52. Zheng ML, Niu DZ, Jiang D, Zuo SS, Xu CC. Dynamics of microbial community during ensiling direct-cut alfalfa with and without LAB inoculant and sugar. J Appl Microbiol. 2017;122:1456-70. https://doi.org/10.1111/jam.13456

53. Parvin S, Wang C, Li Y, Nishino N. Effects of inoculation with lactic acid bacteria on the bacterial communities of Italian ryegrass, whole crop maize, guinea grass and rhodes grass silages. Anim Feed Sci Technol. 2010;160:160-6. https://doi.org/10.1016/j.anifeedsci.2010.07.010 